[Stephens, B., \& Boston, J. (1995). Financing Tertiary Education: An Evaluation of the Todd Report. New Zealand Annual Review of Education, 4, 109-135]

\section{Financing Tertiary Education: An Evaluation of the Todd Report}

\author{
BOB STEPHENS AND JONATHAN BOSTON
}

\section{Abstract:}

This article evaluates the proposals in the Report of the Ministerial Consultative Group (MCG) for funding the expected growth in tertiary student enrolments over the next decade. The Report (commonly known as the Todd Report), published in May 1994, was still under active consideration by the Government at the time of writing. After outlining the context in which the Report was prepared, this article summarises the Report's key policy recommendations and assesses their merits. Particular attention is given to the proposals contained in Option B under which students would be expected to pay 50 percent of their course costs. The article argues that the Report's failure to provide a clear analytical and philosophical framework gives rise to numerous flaws and inconsistencies in its recommendations. The case for significantly higher fees is considered to have little merit.

Tn August 1993, the Minister of Education, Lockwood Smith established a Ministerial Consultative Group (MCG) to advise the Government on how the expected growth in the number of tertiary students should be funded. The MCG was chaired by Jeff Todd, a Senior Partner in Price Waterhouse, and included nine other people drawn from the tertiary sector and the business community. It reported to the Government in May 1994.

The Report made numerous policy recommendations with respect to the tertiary sector, but on the crucial issues relating to the level and structure of state subsidies for tertiary education, the members of the MCG were unable to reach agreement. Three options were presented. Under Option A, student contributions would increase from under 20 percent to 25 percent of course costs by the year 2000; under Option B, student contributions would rise to 50 percent; and under the third option (unofficially known as Option C), the costs of funding additional student places would come from tax revenue, with no increase in student
110 Bob Stephens and Jonathan Boston

contributions. Whilst the Government had publicly rejected Option B, at the time of writing (December 1994) no decisions on the Report's recommendations had been announced.

This evaluation of the Todd Report concentrates on two broad areas of academic and public debate over the appropriate role of the state in the funding of tertiary education. First, there are fundamental philosophical disagreements over the nature of education, the meaning of the principle of equality of educational opportunity and whether rationing educational opportunities should be by ability to benefit or ability to pay. Second, there are analytical and technical issues which include the private and public rates of return to tertiary education, the nature and magnitude of the externalities generated by tertiary courses, the elasticity of demand for student places, the distributional consequences of public expenditure on tertiary education, and likely trends in participation rates.

\section{The Policy Context}

In most OECD countries, including New Zealand, tertiary education has been primarily funded by the state for at least half a century (Boston, 1988; MCG, 1994:204-220; OECD, 1990; Williams, 1992). Prior to 1990 most New Zealand students paid minimal fees and a high proportion of full-time students were eligible for allowances to cover living costs. Tertiary participation rates remained low by OECD standards until at least the early 1990s despite these relatively generous funding arrangements and a policy of open-entry to tertiary institutions, for those aged over 20 years (Pool, 1987; Tertiary Review Group, 1991). From the mid-1980s there was a marked increase in student numbers, and this trend continued into the early 1990s (see Table 1).

Table 1 Funded EFTS places and actual EFTS levels

\begin{tabular}{lrrrrrc}
\hline \multicolumn{1}{c}{ Sector } & $\begin{array}{c}\text { Funded } \\
\text { EFTS }\end{array}$ & $\begin{array}{c}\text { Funded } \\
\text { EFTS }\end{array}$ & $\begin{array}{c}\text { Funded } \\
\text { EFTS }\end{array}$ & $\begin{array}{r}\text { Funded } \\
\text { EFTS }\end{array}$ & $\begin{array}{c}\text { Funded } \\
\text { EFTS }\end{array}$ & $\begin{array}{c}\text { c change } \\
1991 \text { to } \\
1995\end{array}$ \\
\hline University & 63,233 & 68,521 & 72,142 & 75,702 & 78,014 & 23.4 \\
Polytechnic & 45,141 & 49,044 & 52,565 & 54,213 & 54,395 & 20.5 \\
College & 5,735 & 6,560 & 6,758 & 7,028 & 7,092 & 23.7 \\
Wananga & & & 54 & 281 & 473 & - \\
\hline Total Funded EFTS & $\mathbf{1 1 4 , 1 0 9}$ & $\mathbf{1 2 4 , 1 2 5}$ & $\mathbf{1 3 1 , 5 1 9}$ & $\mathbf{1 3 7 , 2 2 4}$ & $\mathbf{1 3 9 , 9 7 4}$ & $\mathbf{2 2 . 7}$ \\
Actual EFTS Levels & $\mathbf{1 1 9 , 0 7 2}$ & $\mathbf{1 2 6 , 4 8 4}$ & $\mathbf{1 3 4 , 8 1 9}$ est $\mathbf{1 3 9 , 4 8 3}$ & & \\
\hline
\end{tabular}

Source: Ministry of Education, 1994. 
The additional fiscal costs generated by this growth, together with pressure from the Treasury $(1984,1987)$ to reduce state tuition subsidies on efficiency and equity grounds, led the Labour Government to consider increasing the level of student contributions. After evaluating various options, including the Higher Education Contribution Scheme (HECS) in Australia, it decided to introduce a standard tertiary fee of $\$ 1,250$ in 1990. This was increased to $\$ 1,300$ in 1991. A fees subsidy was instituted to assist students from low-income backgrounds.

In 1991, the newly-elected National Government announced significant changes to the system of funding tertiary education. These were prompted both by its desire to reduce the fiscal deficit and by its election commitment to implement a new "Study Right" policy guaranteeing "every school leaver access to tertiary education and training as of right" (National Party, 1990:7). A two-tier system of tuition subsidies was introduced in 1992: students commencing their studies before the age of 22 received a tuition subsidy of 95 percent of the Ministry of Education's estimate of course costs for three years; other students received a tuition subsidy of 85 percent in 1992, 80 percent in 1993, and 75 percent in 1994 (Boston, 1992a). Average fees rose from $\$ 1,300$ in 1991 to around $\$ 1,900$ in 1994 , and are expected to exceed $\$ 2,000$ in 1995 (see Table 2).

The abolition of the standard tertiary fee and the introduction of the new subsidy arrangements has resulted in large fee variations between institutions and across the various course categories (see Tables 2 and 3 ). For instance, fees for expensive courses, such as medicine and dentistry, now exceed $\$ 5,000$ per annum for students at Otago University. In fact, those commencing dentistry in 1995 will be charged fees in excess of $\$ 18,000$ per annum. Such fees are exceptionally high by international standards, certainly for undergraduate courses within public tertiary institutions. By comparison, fees for courses in cost category A (e.g., arts, social sciences, commerce, and law) are under $\$ 2,000$ in most tertiary institutions. Table 2 indicates that only Waikato charges fees commensurate with the funding formula provided by the Ministry of Education. Auckland, Canterbury and Victoria have standardised their fees across cost categories and eliminated the Study Right/non-Study Right distinction, whilst Otago, Massey and Lincoln retain the cost categories only. The result is a diversity of fee structures between courses and universities. A similar situation exists in the polytechnics.

The National Government also abolished the system of universal student allowances and replaced it with targeted allowances. To assist
Table 21995 University Student Fees

\begin{tabular}{|c|c|c|c|c|c|}
\hline \multicolumn{6}{|c|}{ UNDIFFERENTIATED STUDENT FEES } \\
\hline \multicolumn{2}{|r|}{ University } & 1994 Fees & 1995 Fees & Increase & \\
\hline \multirow{2}{*}{\multicolumn{2}{|c|}{$\begin{array}{l}\text { Auckland } \\
\text { Canterbury }\end{array}$}} & $\$ 1,792$ & $\$ 1,848$ & $\$ 56$ & \\
\hline & & $\$ 1,500$ & $\$ 1,700$ & $\$ 200$ & \\
\hline \multicolumn{2}{|r|}{ Victoria } & $\$ 1,830$ & $\$ 1,920$ & $\$ 90$ & \\
\hline \multicolumn{6}{|c|}{ DIFFERENTIATED STUDENT FEES } \\
\hline University & \multicolumn{2}{|c|}{1994 Fees } & \multicolumn{2}{|c|}{1995 Fees } & Increase \\
\hline Waikato & Study Righ & Non-SR & Study Right & Non-SR & \\
\hline Category A (other than law) & $\$ 1,400$ & $\$ 1,950$ & $\$ 1,550$ & $\$ 2,100$ & $\$ 150$ \\
\hline Category A (law) & $\$ 1,550$ & $\$ 1,950$ & $\$ 1,700$ & $\$ 2,100$ & $\$ 150$ \\
\hline Category B (psych/geog) & $\$ 1,700$ & $\$ 2,150$ & $\$ 1,850$ & $\$ 2,300$ & $\$ 150$ \\
\hline Category B (comp/act/tech) & $\$ 1,750$ & $\$ 2,300$ & $\$ 1,900$ & $\$ 2,450$ & $\$ 150$ \\
\hline Category C & $\$ 1,950$ & $\$ 2,500$ & $\$ 2,100$ & $\$ 2,650$ & $\$ 150$ \\
\hline Category D & $\$ 2,300$ & $\$ 2,800$ & $\$ 2,450$ & $\$ 2,950$ & $\$ 150$ \\
\hline Category I & $\$ 1,700$ & $\$ 2,150$ & $\$ 1,850$ & $\$ 2,300$ & $\$ 150$ \\
\hline Massey & \multicolumn{2}{|c|}{1994 Fees } & \multicolumn{2}{|c|}{1995 Fees } & Increase \\
\hline Category A & \multicolumn{2}{|c|}{$\$ 1,645$} & \multicolumn{2}{|c|}{$\$ 1,680$} & $\$ 35$ \\
\hline Category B & \multicolumn{2}{|c|}{$\$ 1,870$} & \multirow{2}{*}{\multicolumn{2}{|c|}{$\$ 1,945$}} & $\$ 75$ \\
\hline Category C & \multicolumn{2}{|c|}{$\$ 2,070$} & & $\$ 2,155$ & $\$ 85$ \\
\hline Category D & \multicolumn{2}{|c|}{$\$ 2,225$} & \multicolumn{2}{|c|}{$\$ 2,435$} & $\$ 210$ \\
\hline Category E & \multicolumn{2}{|c|}{$\$ 2,225$} & \multicolumn{2}{|c|}{$\$ 2,450$} & $\$ 225$ \\
\hline Category $\mathrm{H}$ & \multicolumn{2}{|c|}{$\$ 3,000$} & \multicolumn{2}{|c|}{$\$ 3,500$} & $\$ 500$ \\
\hline
\end{tabular}

Key A: Business Studies, Humanities, Social Sciences

B: Science, Psych, Nursing Studies, Computing Sciences

C: Applied Science, Technology, Postgraduate Category A

D: Postgraduate Category B

E: Postgraduate Category C

\begin{tabular}{lccc} 
H: Veterinary Science & & \\
\hline Lincoln & 1994 Fees & 1995 Fees & Increase \\
Category A & $\$ 1,296$ & $\$ 1,384$ & $\$ 88$ \\
Category B & $\$ 1,888$ & $\$ 2,016$ & $\$ 128$ \\
Category C & $\$ 2,240$ & $\$ 2,392$ & $\$ 152$ \\
\hline
\end{tabular}

Key A: Commerce, Management

B: Resource Studies, Science, Parks \& Recreation, Agriculture, Horticulture

C: Landscape Architecture, Postgraduate

\begin{tabular}{lccc}
\hline Otago & 1994 Fees & 1995 Fees & Increase \\
OU1 (arts, commerce) & $\$ 1,250$ & $\$ 1,520$ & $\$ 270$ \\
OU2 (sci, mus, comp) & $\$ 1,750$ & $\$ 1,920$ & $\$ 170$ \\
OU3 (surv, health) & $\$ 2,250$ & $\$ 2,550$ & $\$ 300$ \\
OU4 (dent, new) & $\$ 7,600$ & $\$ 18,072$ & $\$ 10,472$ \\
$\quad$ (dent, existing) & $\$ 7,600$ & $\$ 10,173$ & $\$ 2,573$ \\
OU5 (medicine) & $\$ 5,250$ & $\$ 5,540$ & $\$ 290$ \\
\hline
\end{tabular}

Source: New Zealand Vice-Chancellors' Committee, 1994. 
Table 3 Annual Public Tuition Subsidy by Course Category - 1994

\begin{tabular}{|c|c|c|c|}
\hline & Cost Category & $\begin{array}{l}\text { Study Right } \\
\text { Subsidy }\end{array}$ & $\begin{array}{l}\text { Non-Study } \\
\text { Right Subsidy }\end{array}$ \\
\hline A: & $\begin{array}{l}\text { Arts, Social Sciences, Accountancy, General } \\
\text { including Community Education, Law }\end{array}$ & $\$ 6,250$ & $\$ 4,934$ \\
\hline B: & $\begin{array}{l}\text { Agriculture (non-degree), Architecture (non-degree), } \\
\text { Computing, Engineering (non-degree), Fine Arts, } \\
\text { Music, Nursing, Science, Trades }\end{array}$ & $\$ 9,468$ & $\$ 7,475$ \\
\hline C: & $\begin{array}{l}\text { Agriculture (degree), Architecture (degree), } \\
\text { Doctoral/Hons (A), Engineering (degree), } \\
\text { Health Sciences }\end{array}$ & $\$ 11,927$ & $\$ 9,416$ \\
\hline D: & Doctoral/Honours (B) & $\$ 21,860$ & $\$ 17,258$ \\
\hline E: & Doctoral/Honours (C) & $\$ 26,116$ & $\$ 20,618$ \\
\hline F: & Dentistry & $\$ 38,317$ & $\$ 30,251$ \\
\hline G: & Medicine & $\$ 23,751$ & $\$ 18,751$ \\
\hline $\mathrm{H}:$ & Veterinary & $\$ 18,360$ & $\$ 14,495$ \\
\hline I: & Teaching & $\$ 9,187$ & $\$ 7,253$ \\
\hline P: & PTEs & $\$ 5,323$ & $\$ 4,203$ \\
\hline$X:$ & Extramural & $\$ 6,250$ & $\$ 4,934$ \\
\hline
\end{tabular}

Source: Ministry of Education, 1994.

students to pay their fees and cover their living costs, a governmentfunded, income-contingent loans scheme was introduced. Students are charged a positive real interest rate and are required to repay their loans once their income exceeds $\$ 13,520$ per annum at the rate of 10 cents in the dollar.

In keeping with its objective of increasing participation rates in tertiary education, National has funded additional EFTS (Equivalent Full-Time Student) places in the tertiary sector (see Table 1). The number of funded EFTS places rose from 114,109 in 1991 to 139,974 in 1995, an increase of 22.7 percent. However, in order to accommodate this growth within tight fiscal limits, the Government reduced the average level of funding per EFTS. In nominal terms, expenditure per funded EFTS fell from $\$ 8,704$ in 1991 to $\$ 7,955$ in 1995 , a reduction of 8.6 percent; in real terms the reduction has been over 15 percent. In response, tertiary institutions have substantially increased their fees and reduced the
Table 4 Public Expenditure on Student Allowances, Loans And Tuition Subsidies

\begin{tabular}{lccc}
\hline & $\begin{array}{c}\text { Allowances } \\
\text { (\$ millions) }\end{array}$ & $\begin{array}{c}\text { Tuition } \\
\text { Loans* } \\
\text { (\$ millions) }\end{array}$ & $\begin{array}{c}\text { Subsidies } \\
\text { (\$ millions) }\end{array}$ \\
\hline $1989 / 90$ & 297.5 & & \\
$1990 / 91$ & 304.9 & & 993.2 \\
$1991 / 92$ & 286.8 & 92.9 & 1059.4 \\
$1992 / 93$ & 238.6 & 232.3 & 1096.6 \\
$1993 / 94$ & 251.4 & 329.5 & 1100.9 \\
$1994 / 95$ (est) & 273.6 & 403.5 & 1113.6 \\
\hline
\end{tabular}

* Most of these loans will eventually be repaid. It is debatable whether they should be included in current expenditure.

Source: Ministry of Education 1994.

quality of education. Student-staff ratios have risen from 14.1:1 in 1988 to 16.8:1 in 1991 and 18.5:1 in 1993. While the Todd Report (p. 222) mistakenly implied that this is an improvement in productivity, the reality is increased academic workloads, more stress, less contact time per student and less research time (Boyd and Wylie, 1994).

In 1993/94, public expenditure on tertiary education was almost $\$ 2$ billion, or 40 percent of Vote: Education. This included $\$ 1,088$ million on subsidies to tertiary institutions, \$269 million on student allowances, $\$ 347$ million on repayable student loans, and \$282 million on training programmes and related activities (see Table 4). For 1995, the Government has allocated an additional $\$ 13$ million for tuition subsidies - it will fund more places but has again reduced funding per EFTS.

\section{The Establishment of the Todd Task Force}

National's tertiary policies have attracted a good deal of criticism. In particular, representatives of the tertiary sector have been concerned about:

- the discriminatory nature of the Study Right policy and its potentially adverse affect on mature students and those taking lengthy degree programmes;

- the possible impact of higher fees and cuts in income support on participation rates of students from low-income backgrounds; 
- the impact on student hardship and poverty of the tight targeting of student allowances and the relatively low borrowing limits for living costs;

- the negative impact of the loans scheme on gender equity, student indebtedness, and effective marginal tax rates; and

- the consequences of the continuing reduction in real levels of funding per EFTS and deteriorating student:staff ratios on the quality of tertiary courses and the international standing of New Zealand universities.

By 1993, National realised that its tertiary education policies were inconsistent. Tertiary education remained one of the few major spending areas where ministers and their economic advisers believed that there might be some scope for expenditure cuts to deal with the continuing sizeable budget deficit. The Government was also firmly committed to increasing participation rates in the tertiary sector as this was seen as a way of relieving unemployment and producing economic growth (Ministry of Education, 1993). But it recognised that further substantial fee increases - which would be inevitable if there were significant cuts to tertiary funding - would attract concerted political opposition.

The Government established the Ministerial Consultative Group (MCG) in August 1993 to seek advice on how the desired (and expected) growth in the tertiary sector should be funded. The terms of reference required the Task Force to comment on a range of matters including: the nature and level of the public and private benefits from tertiary education; the appropriate balance between private and public contributions; ways of encouraging continuing improvement in the efficiency of institutional and delivery mechanisms in tertiary education; the relationship between levels of tuition fees paid by students and participation rates; the international evidence on the relationship between student fees and the quality and diversity of education opportunities; and the appropriate share of total education expenditure going to tertiary education (MCG, 1994:163-165). In making its recommendations, the MCG was urged to have regard to the Government's objectives for tertiary education. These included: the development of a culture of lifetime learning; getting better value for money from public expenditure on tertiary education by improving efficiency, making the system responsive to student, employer and societal needs, and ensuring that the most cost-effective providers receive government resources; providing fair access to tertiary education for all New Zealanders; and ensuring stable and fiscally sustainable policies for tertiary education (MCG, 1994:163-164).

The members of the MCG were carefully chosen. The Government wanted to ensure that the Task Force had a strong representation from the tertiary sector so that its recommendations would carry weight with the relevant communities of interest. But it also wanted a Task Force that would be well disposed to the idea of higher student contributions. Of the ten members, only the "student" representatives (Kirsty Graham and Jason Hemopo) were expected to defend the status quo or seek higher government subsidies. By contrast, several members were well-known for their market-liberal views (e.g., Robert McLeod and Grant Scobie), and some of the educationalists on the Task Force were recognised amongst their peers as being towards the conservative end of the political spectrum. Given the MCG's composition, it is hardly surprising that it failed to reach agreement on the key policy issues; nor is it surprising that the majority of its members believed that the expansion of the tertiary sector should be funded, in part if not completely, via higher student contributions.

\section{The Recommendations of the Todd Report}

Members of the MCG agreed on the broad social philosophy that New Zealand governments should seek a high level of social well-being and prosperity, and on the desirability of enhancing participation rates in tertiary education and training. As the Report (MCG, 1994:13) stated:

Every citizen must have access to an education which fits them for productive employment throughout their lives and supports an increasing standard of living for all New Zealanders. This incorporates the need to recognize the equal rights to education of women and minority groups and the wider social and cultural benefits of education. There is also a need to ensure that every citizen is equipped to play a full part in the life of a prosperous and democratic society.

The MCG adopted as its overriding principle the notion that:

access to high quality education and training is a right that the state should, as far as it is able, guarantee and promote.

Supplementary goals included the promotion of excellence in education and research, the preservation of institutional autonomy, the fostering of innovative and responsive providers, and the creation of a predictable policy environment. 
Two inter-related issues dominated the policy debates within the MCG. The first centred on whether the existing level and structure of public subsidies was justified. The second concerned the best method of funding the expected growth in tertiary participation rates. In addressing these issues, the MCG eventually divided into three main camps.

\section{Option A}

The four supporters of Option A argued that the state should remain the dominant funder of tertiary education and endorsed most aspects of the existing policy framework (including the student loans scheme, targeted allowances and the EFTS funding system). They contended, however, that the system of allowances should be harmonised with income support payments. Private training should also be expanded with public support. A relatively high level of state funding was justified on at least four grounds: that tertiary education brought significant benefits to the whole of society; that a large increase in fees might have a negative impact on participation rates, especially for those from poorer backgrounds, and place additional financial pressures on many families; that such a strategy was consistent with the stance of most other OECD countries; and that the share of public expenditure on education devoted to the tertiary sector was in line with international practice.

With respect to funding the expected growth in student numbers, supporters of Option A were mindful of the tight fiscal constraints in which the Government was operating (at least in the initial stages of the Report's preparation), the Government's strong opposition to further expenditure increases (especially if they entailed tax increases), and the Ministry of Education's relatively modest estimates of the likely growth in tertiary enrolments and EFTS places until the year 2011. According to the Ministry, the most "probable" outcome was a medium growth in participation rates and a low fertility rate (MCG, 1994:39). Under this scenario, the expected growth in EFTS places was estimated to be about 1.2 percent until the year 2002 and then 1.4 percent from 2002 until 2011, a substantial reduction on the 8 percent per annum average increase in publicly-funded EFTS places between 1990 and 1993. The expected growth in student numbers could be funded by means of a modest, incremental reduction in per capita EFTS tuition subsidies to around 75 percent of course costs by the year 2000 , giving average fees of $\$ 2,500$ per annum. Two of the members supporting Option A argued that any increase in student numbers beyond the year 2000 would have to be funded primarily by the state, while the other two members considered that Option B could be viable in the longer term (MCG, 1994:157).

\section{Option B}

The four proponents of Option B also endorsed the concept of an income-contingent loans scheme and targeted student allowances. However, they argued that the level of "valuable public benefits" (p. 21) from tertiary education and training were not sufficient to justify the current level of tuition subsidies. The existing policy regime was also inequitable as over 60 percent of participants in the tertiary sector were from higher income families and were in a position to make a larger financial contribution (p. 21). By contrast, those from poorer backgrounds were much less well represented within the tertiary sector. The supporters of Option B also argued that it was unfair for those who were the principal beneficiaries of higher education (i.e., the students) to pay only a small proportion of the direct costs of their education.

As an illustration, the present average value of the additional income earned by a male graduate is around $\$ 150,000$ (see note at end). Currently such a graduate would typically contribute no more than 20 percent of tuition costs. The balance of tuition costs is met by the taxpayer. In effect, the taxpayer confers a large capital grant on graduates. Similar grants are not made available to people who wish to establish a business. For example, a young farmer buying a herd to become a sharemilker could not expect the taxpayers to meet 80 percent of the costs (MCG, 1994:20).

Proponents of Option B argued that tuition subsidies should be gradually reduced to about 50 percent of course costs by the year 2000 . Two members wanted a more gradual transition, and full research to ensure increased participation of under-represented groups. It was argued that the savings achieved from this cut in state funding should be used to fund additional places in tertiary institutions, to provide targeted assistance to those from lower-income backgrounds wishing to access tertiary education, and to assist students from under-represented backgrounds attending school or early childhood learning centres. Several of those who supported Option B circulated papers prior to the completion of the Report which suggested that the fiscal savings from reduced public tuition subsidies could be used to cut the top marginal tax rate (McLeod and Scobie, 1994a, 1994b). This idea, however, was not mentioned in the Report.

Proponents of Option B recognised that changes to the student loans scheme would be needed if tuition subsidies were reduced by the amount recommended. They suggested that the existing levy rate of 10 cents per dollar might need to be increased to 15 percent for those 
earning above $\$ 30,875$ (the rate at which the top marginal tax rate of 33 percent currently applies) (p. 142). They also suggested that "a market rate of interest should apply and interest should accrue where income is insufficient to require full repayment of interest and principal", that "graduates could be offered an appreciable inducement to repay contingent debt early", and that "consideration should be given to requiring students to purchase life insurance sufficient for the loan to be repaid at death" (p. 142). The latter proposal would, of course, significantly alter the income-contingent nature of the current loans scheme.

\section{Option C}

The two members of the MGC who rejected both Options A or B did not outline their preferred approach in the same detail as the supporters of the other options. Nor were their proposals given the official title "Option C". Nonetheless, in effect, their views constitute a third, and perfectly legitimate, approach to funding tertiary education. Under this approach, per capita tuition subsidies would be kept at their present levels in real terms and the expected growth in tertiary education would be funded wholly by the state (p. 158). The case for substantial tuition subsidies was justified on similar grounds to those used by the supporters of Option A. However, emphasis was also given to the considerable hardship being faced by many students under the existing funding regime, the implications of higher fees on the level of student indebtedness, and the adverse effects of increased private contributions on inter-generational equity (p. 159). Recommendations included the abolition of Study Right, the introduction of a rolling triennial funding system based on EFTS places), and a reduction in the age limit at which student allowances are means tested on the basis of student income alone from 25 years to 20 years of age (p. 158).

\section{A Critique of the Todd Report}

The Todd Report generated a vigorous public debate and prompted the preparation of numerous detailed rebuttals (see, for instance, Boston, 1994; Brooke, 1994; Devlin, Hansen and Knowles, 1994; Dutton, 1994 New Zealand University Students' Association, 1994; Rosenberg, 1994; St John, 1994). It is not possible here to address all the issues raised by the Report's findings and varied recommendations. Hence, we will make some general observations on the quality of the Report's analysis and then focus more specifically on the weaknesses of Option B.
For a Report which is reputed to have cost taxpayers over $\$ 400,000$, the document must be regarded as poor value for money There was extensive repetition, especially in the lengthy chapters on Options A and $B$, albeit with different emphases and conclusions. No new empirical data or research findings were provided on important issues which underpin the policy recommendations (e.g., the public and private rates of return to tertiary education in New Zealand and how these have been affected by recent changes in tuition costs and tax rates; the externalities generated by tertiary education; the possible impact of higher fees on participation rates; the financial problems facing students under existing policy arrangements and the impact of this on academic performance, stress levels, family relationships and so forth; and the capacity of the current loans scheme to accommodate substantially higher fees). The only original research was Annex 4, which analysed the current trends in, and future prospects for, tertiary student enrolments.

\section{The nature of education and the principle of equality of educational opportunity}

The Report was confused as to the nature of education. Most of the analysis was cast within the framework of the discipline of economics. Education was thus treated as if it were primarily an investment commodity for future employment prospects and economic growth. By contrast, the Report also contended that access to tertiary education and training was a "right". However, the precise nature of this right and its implications for public policy were not addressed.

Similarly, the authors of the Report appeared to support the principle of equality of educational opportunity. Yet no attempt was made to explore the meaning of this principle. Needless to say, how this principle is interpreted, and what weight it is given, is of crucial importance in policy terms. For example, if it means that people of similar ability should have equal access to cheap tertiary courses, such as those in cost category A (see Table 3), then in accordance with this relatively weak interpretation, charging high fees for expensive courses will not breach the principle. By contrast, suppose that the principle means that people of similar ability should have equal access to all tertiary courses, including the most expensive ones like medicine and dentistry. On this much stronger view, a policy regime involving significant fee differentials and high fees for expensive courses would breach the principle. The stronger view has held sway in most democratic countries during the post-war period. This appears to explain 
why most countries either charge no fees at the tertiary level or have relatively flat fees, at least within public tertiary institutions.

Surprisingly, the Report gave little consideration to the likely impact of reduced tuition subsidies on fee differentials and, in particular, the fees charged for expensive courses. Nor did it examine how a more highly differentiated fee structure would affect the course preferences of people from different socio-economic backgrounds. The Report's silence on such matters suggests that most members of the MCG supported a relatively weak interpretation of the principle of equality of educational opportunity. Hence, they were not concerned if high fees were charged for expensive courses, even if this deterred those from disadvantaged backgrounds taking such courses. Of course, it might be argued that the student loans scheme "solves" the equity problems generated by large fee differentials by enabling those from poorer backgrounds to borrow to cover high-cost courses. But such an argument carries little force. It is not unlike saying that those from disadvantaged backgrounds have an equal opportunity to buy expensive houses by virtue of the fact that there are borrowing facilities available. Moreover, if the right to study dentistry means no more than a right to borrow $\$ 100,000+$ from the state, then this is a very weak notion of educational rights.

\section{New Zealand's international treaty obligations}

One surprising omission from the Report was any mention of New Zealand's international treaty obligations and the implications of these for the funding of tertiary education. New Zealand has ratified the International Covenant on Economic, Social and Cultural Rights. Article 13.2 states that:

Higher education shall be made equally accessible to all on the basis of capacity by every appropriate means, and in particular by the progressive introduction of free education.

The wording of this Article is very clear. It commits parties which have ratified the Covenant to the "progressive introduction of free education". This can only mean lower rather than higher fees. Both Options A and $B$ are plainly inconsistent with this objective and thus in breach of the country's international treaty obligations. Although this matter was drawn to the attention of the MCG, the Task Force appeared to give little weight to such considerations in its deliberations.
The cost and affordability of funding the projected growth in student numbers

The prime rationale for establishing the MCG was to consider how the expected growth in student enrolments during the next decade should be funded. Despite this, the Report provided no estimates of the likely cost to the Government of such growth. Nor did it contain any detailed costings of Options A and B. Further, it furnished no data on how much revenue was likely to be generated by the student loans scheme and whether this income stream would be sufficient to fund the anticipated growth in student numbers. Yet, despite this dearth of basic facts and figures, most members of the MCG appear to have assumed that any further expansion of the tertiary sector is beyond the capacity of the state to fund. This assumption, however, is open to serious doubt.

If the Ministry's estimates are correct, a 1.2 percent increase in EFTS places would cost the Government around $\$ 17$ million per annum, based on expenditures in Table 4, other things being equal. It would be difficult to sustain an argument that an increase of this magnitude is not affordable. After all, even if economic growth averaged only 2 percent a year - about the post-war average - an increase in public expenditure of only 1.2 percent a year on tertiary education would result in a fall in the proportion of the country's gross domestic product devoted to the tertiary sector.

Of course, if the Ministry's projections are too conservative, or if there is an increase in the real level of public funding per EFTS (e.g., in order to enhance the quality of tertiary education), then the figure of $\$ 17$ million would be too low. Nevertheless, it is implausible to suggest that the Government currently lacks the capacity to inject further funds into the tertiary sector. Economic growth has averaged at least 4 percent since 1992 , and this relatively strong growth is expected to continue, at least in the short term. At the time of the 1993 budget - several months before the establishment of the MCG - the financial deficit for 1993/94 was forecast to be around $\$ 2.3$ billion (or about 3 percent of GDP) with the deficit declining to about $\$ 1.1$ billion in 1995/96 (Richardson, 1993:40). A year later, however, the Treasury was forecasting a surplus in the Crown's operating balance of almost $\$ 1$ billion for 1993/94 and a surplus in excess of $\$ 3$ billion for 1995/96 (Birch, 1994:63). Hence, while there may have been a fiscal imperative to limit further increases in expenditure on tertiary education when the MCG commenced its deliberations, this had largely disappeared by the time it tabled its Report. Unfortunately, the MCG made no attempt to adjust its findings to reflect the rapidly changing fiscal outlook. 


\section{A Critique of Option B}

Option B supporters made no attempt to justify higher fees primarily on fiscal grounds. Instead, they invoked other arguments: that higher fees were unlikely to affect participation rates adversely; that the private rate of return on human capital was high; that investment in education was given favourable tax treatment; that income-contingent loans were an efficient and equitable method for students to pay for their education; and that there were positive distributional effects from targeting assistance to students from under-represented backgrounds. The following analysis assesses the merits of these arguments.

\section{Participation rates and fees}

There is limited empirical evidence overseas, and none in New Zealand, on the impact of substantial fee increases on tertiary participation rates. It might be contended that the tertiary fee increases since 1990 have not adversely affected the growth in participation rates in New Zealand. Hence, further substantial increases in fees are compatible with the objective of higher participation rates. However, the recent growth in student numbers is probably best seen as an increase in demand for tertiary education resulting from the combined impact of improved school retention rates, the economic recession and changing social attitudes. The independent impact that fees have on demand cannot be determined from these results.

What effect fees averaging 50 percent of course costs would have on participation rates is difficult to assess. If such fees are viewed by students as up-front costs, then a substantial reduction in participation could be anticipated and this is most likely to be largest for the underrepresented groups whose participation is meant to be increased. If, on the other hand, fee payments were deferred through an extended loans scheme until students started earning, the effect could be minimised to rate of return considerations (see below).

Whatever the impact of 50 percent fees on the overall level of student demand, fees of this magnitude are likely to increase the demand for courses of a more vocational nature, such as accounting and law, and reduce demand for those of a more conceptual and querying nature, like sociology and philosophy. Individuals will have greater certainty of an income from which to repay their loans, especially in the immediate future, from the vocational courses, but the societal benefits may not be as large over a longer-time horizon. Debt minimisation could also be expected to encourage students into shorter and lower-cost courses, away from the longer and more expensive courses of medicine and architecture (unless there are offsetting changes in earnings differentials). Debt minimisation has already resulted in students undertaking both more credits and more part-time paid employment than is academically desirable, thereby reducing the quality of their educational experience. These inter-related impacts were not addressed by the proponents of Option B.

\section{Rates of return on human capital}

Option B treated education as an investment, where rational individuals would weigh up the relative costs and benefits of different uses of their time and money:

When a person spends time and resources in obtaining educational qualifications or training they expect to receive a return in future years (p. 109).

Option B recognised that the rewards were both monetary and nonmonetary ("factors such as personal development and satisfaction, or enhanced appreciation and understanding of culture can be as important as financial rewards"). It was argued that the additional lifetime earnings represent an asset with the value of $\$ 150,000$. On this basis, tuition costs of around $\$ 6,000$ would represent only 4 percent of the "asset financial value" (p. 110). The implication was that, on average, tertiary education was an extremely profitable investment. Further, that investment was subsidised by the state, making it a favourable investment compared to other forms of investment (see below).

Again, the issues are more complex than indicated in the Report. First, as noted in the Report, the figure of $\$ 150,000$ is the additional lifetime earnings of a male graduate over a school-leaver with no qualifications. But the correct comparison is with a bursary qualification, giving a present value of earnings differential of $\$ 90,000$ (p. 129). Second, not all of this differential can be attributed to tertiary education; a proportion can be attributed to innate ability, parental background, and the type of occupational or industrial labour market (Blaug, 1976; Stephens, 1993a). Estimates of the "alpha co-efficient" (i.e., the proportion of additional earnings attributed to tertiary education) range from 0.2 to 1.0 , with typical estimates being in the range of 0.5 to 0.8 (Blaug, 1970). Equally, it is presumed that the present age-related earnings differential will persist through the lifetime of a graduate - but this presumption is open to question. 
Table 5 Rates of Return on Human Capital

\begin{tabular}{|c|c|c|c|c|c|c|c|c|c|}
\hline \multicolumn{5}{|c|}{$\begin{array}{l}\text { Bachelor's degree compared with 7th Form } \\
\text { school leaver }\end{array}$} & \multicolumn{5}{|c|}{$\begin{array}{l}\text { Postgraduate degree compared with } \\
\text { Bachelor's degree }\end{array}$} \\
\hline & \multicolumn{2}{|c|}{$\begin{array}{l}\text { Private } \\
\text { Return }\end{array}$} & \multicolumn{2}{|c|}{$\begin{array}{l}\text { Public } \\
\text { Return }\end{array}$} & & \multicolumn{2}{|c|}{$\begin{array}{l}\text { Private } \\
\text { Return }\end{array}$} & \multicolumn{2}{|c|}{$\begin{array}{l}\text { Public } \\
\text { Return }\end{array}$} \\
\hline $\begin{array}{l}\text { Alpha } \\
\text { Coefficient }\end{array}$ & 1.0 & 0.5 & 1.0 & 0.5 & $\begin{array}{l}\text { Alpha } \\
\text { Coefficient }\end{array}$ & 1.0 & 0.5 & 1.0 & 0.5 \\
\hline Males & & & & & Males & & & & \\
\hline $\begin{array}{l}\text { Non-Polynesian } \\
\text { Maori } \\
\text { Pacific Island }\end{array}$ & $\begin{array}{r}8.86 \\
6.69 \\
23.98\end{array}$ & $\begin{array}{r}4.43 \\
3.34 \\
11.99\end{array}$ & $\begin{array}{r}8.32 \\
6.24 \\
18.95\end{array}$ & $\begin{array}{l}4.16 \\
3.12 \\
9.48\end{array}$ & $\begin{array}{l}\text { Non-Polynesian } \\
\text { Maori } \\
\text { Pacific Island }\end{array}$ & $\begin{array}{l}4.34 \\
5.39 \\
3.93\end{array}$ & $\begin{array}{l}2.17 \\
2.70 \\
1.96\end{array}$ & $\begin{array}{l}4.09 \\
5.04 \\
3.13\end{array}$ & $\begin{array}{l}2.05 \\
2.52 \\
1.56\end{array}$ \\
\hline Females & & & & & Females & & & & \\
\hline $\begin{array}{l}\text { Non-Polynesian } \\
\text { Maori } \\
\text { Pacific Island }\end{array}$ & $\begin{array}{r}9.66 \\
12.73 \\
27.41\end{array}$ & $\begin{array}{r}4.83 \\
6.37 \\
13.71\end{array}$ & $\begin{array}{r}7.16 \\
9.55 \\
18.90\end{array}$ & $\begin{array}{l}3.58 \\
4.78 \\
9.45\end{array}$ & $\begin{array}{l}\text { Non-Polynesian } \\
\text { Maori } \\
\text { Pacific Island }\end{array}$ & $\begin{array}{r}6.15 \\
3.62 \\
-2.35\end{array}$ & $\begin{array}{r}3.07 \\
1.81 \\
-1.17\end{array}$ & $\begin{array}{r}4.84 \\
2.85 \\
-1.82\end{array}$ & $\begin{array}{r}2.42 \\
1.43 \\
-0.91\end{array}$ \\
\hline
\end{tabular}

Source: Based on Poot and Stephens (1994), derived from Census 1991.

Third, the appropriate comparative information is not emotive earningsgap data but the rate of return on human capital. Poot and Stephens (1994), using 1991 Census data, calculated a variety of rates of return employing an approximation to the normal internal rate of return formula based on methodology developed by Sapsford and Tzannatos (1993). Table 5 shows the rates of return using an alpha co-efficient of 1.0 and 0.5 for non-Polynesian, Maori and Pacific Island males and females for a bachelor's degree compared to a seventh-form leaver. The data does not distinguish between types and costs of degrees, nor income by occupational groups. The results show that if all of the extra income is attributed to a university degree (alpha co-efficient of 1.0), then the real rate of return for non-Polynesian males is close to that at which students can borrow money, but at an alpha co-efficient of 0.5 , the private rates of return are lower than the interest rate on student loans. The rates of return are generally lower for Maori males than Pakeha males. The results for females are a little problematic as they are averages for those in and out of the workforce, but are higher than the male figure because female seventh form leavers have lower labour force participation rates than tertiary graduates (Brosnan and Rea, 1991). Likewise, the high rate of return for Pacific Island males is an indication of the high unemployment rate (and hence low foregone earnings) for those leaving school at the end of seventh form.
Public rates of return are lower than private rates of return, taking into account the full fiscal costs of education, but incorporating income tax on earnings as a benefit. The public rate of return excludes any estimate of the spillovers or external benefits from education. Proponents of Option B appeared to be of the view that the external benefits of tertiary education were roughly equal to the private benefits. If the external benefits are as great as suggested and if the public rates of return in Table 5 are added to these external benefits, then on current policy settings the overall public (or the social) return would far exceed the private rate of return. On these assumptions there is certainly no case for cutting current subsidy levels. On the contrary, there might well be a case for increasing them.

Even at the 1993 fees levels used in these calculations, tertiary education was not a profitable private investment unless all of the additional earnings could be attributed to that education. Increasing fee levels would further reduce that return, unless offset by widening earnings differentials. Widening earnings differentials can only come from a relative reduction in labour supply. That infers that the immediate objective of increased tertiary participation, to enhance economic growth, would only have been partially successful. It is problematic whether the general population would accept as equitable an increase in gross salaries, to offset the higher tuition costs, for medics, architects, engineers and other graduates. Further, since it would be impossible to restrict any wage increases solely to new graduates, many existing graduates would enjoy, in effect, a higher private rate of return. This raises important inter-generational equity issues.

\section{Tax effects}

The MCG Report argued that the tax treatment of those who invest in tertiary education is favourable compared with those who invest resources in other activities:

Investment in human capital is generally favourably treated under the income tax system. Accretions in the value of human capital are non-taxable, while the costs of undertaking tertiary education are, in

effect, deductible. This is not the case for most other investments (p. 127).

Whilst the MCG Report never clearly presented its arguments, as St John and Skilling (1994) indicated, the argument seems to be that the playing field has been tilted in favour of investment in tertiary education, thereby violating the principle of horizontal equity, and providing the 
justification for reducing the degree of subsidy from the taxpayer to students. St John and Skilling showed that investment in human capital cannot be compared with investment in a capital asset as the latter has physical existence which can be transferred and realised, while the former cannot be used as collateral for a loan. Accretions to any capital asset are currently non-taxable. Also, with physical capital investment, costs are deductible from business income, whereas the costs of investing in education are not. Hence, there is a disincentive to invest in education. This tax disincentive increases with every rise in student fees.

Jackson (1994) used a different taxation argument to criticise Option B. He argued that students already paid for the cost of their education, not at the time they were studying, but later through the additional tax revenue generated from their higher earnings. If much of the addition to earnings is due to education, as in the human-capital model, then much of the tax paid on those additional earnings could equally be attributed to education. Jackson estimated that:

For the 1991 year, graduates are estimated to have paid $\$ 545$ million more in (income) taxes than they would have paid without the additional income generated by their qualifications. The Government outlays to the universities for all purposes totalled $\$ 555$ million in that year. (1994:1)

This estimate is based on 80 percent of the additional income and taxation accruing from education. But the tax gain is an underestimate since it ignores the GST paid on additional consumption expenditures. Jackson pointed out that the income gains from non-university tertiary education are smaller, so that less tax revenue will be generated. If Jackson is correct, then even with a top marginal tax rate of 33 cents, there seems little justification for cutting public subsidies to tertiary education.

\section{Student loans}

Catherall (1994), reporting on a CM Research survey, showed that student debt rose by 35 percent in 1994, with university students having an average debt of $\$ 8,262$ when interest on loans is included, and $\$ 5,866$ when interest is excluded. Polytechnic students had a lower average debt. Those from wealthier backgrounds had larger debts, mainly because they were not eligible for student allowances. These results, based on the first two years of the loans scheme, show the size of debt that students could incur when fees were below $\$ 2,000$, as well as the compounding impact of interest on debt.
Although it is sometimes argued that income-contingent loans are more equitable and efficient than student grants to offset student living costs and fees (Barr, 1987; Glennerster, 1993), the current loans scheme is not without its problems. These would be compounded if fees were significantly increased and the loans scheme extended in the manner envisaged by the proponents of Option B. Brooke (1994) analysed the combined impact of larger loans and market interest rates on student's ability to repay debt. She considered the case of a secondary teacher borrowing $\$ 5,000$ per annum over four years, with a cumulative interest at 7 percent per annum, giving a debt of $\$ 22,976$ on completion. With normal salary progression and repayment rates, after ten years the teacher would have repaid $\$ 19,050$, but would still have a debt of $\$ 19,000$. Moreover, the 7 percent interest rate included in her calculations is clearly too low. Market interest rates at the time of writing had risen to over 10 percent, but without corresponding increases in salary levels.

Brooke (1994) gave a further example of dentists. With course fees of over $\$ 18,000$ per annum from 1995 (Table 2), earnings would have to be 70 percent higher than the current average income of dentists of $\$ 53,900$ if debts were to be repaid during a typical working lifetime. There would be further difficulties for those who had a period out of the workforce as a result of child rearing or unemployment because the debt would continue to increase in real terms through that period. Knowledge of this future debt is likely to reduce tertiary participation by the underrepresented groups whom Option B supporters purported to assist.

A further issue relates to effective marginal tax rates (EMTR). A major thrust of the 1984-1990 tax reforms was the lowering of marginal tax rates for high income earners for reasons of economic efficiency and work incentives (Stephens, 1993b). However, as envisaged under Option B, marginal tax rates would rise again for medium-to-high income earners. while those with student loans earning between $\$ 15,000$ and $\$ 30,875$ would continue to face an EMTR of at least 38 percent, those earning above $\$ 30,875$ would face an EMTR of at least 48 percent. Increasing the tax rate in this way would lower the rate of return on student investments in education, thereby reducing the incentive to participate in higher education.

\section{Distributional issues}

Option B supporters stressed that current tertiary subsidies benefit the wealthy disproportionately. It was claimed, for instance, that " 73 percent of 18-19 year old university students came from households with 
incomes above $\$ 35,567$, compared to only 44 percent of all 18-19 year olds" (p. 115). Yet the argument that students from wealthy backgrounds could "afford to make a greater contribution" (p. 111) is at variance with the philosophy underpinning Option B, that students themselves, rather than their parents, should pay for their education (i.e., once they were in the workforce and earning over the relevant threshold). If fees are to be charged on the basis of the relative size of public and private benefits, and if students are to pay only as they begin to receive the private benefits of their tertiary education, then parental income levels are irrelevant in the setting of fee levels.

The middle-class capture argument which pervades the Treasury's (1987) thinking, and underlies the arguments above, mistakenly considers that universities are a vehicle for income redistribution. Instead, the function of universities is to educate those most able to benefit from learning (Bertram, 1988; Stephens, 1993a). Subsidies in tertiary education are thus to assist those who can benefit from education but are otherwise unable to afford it, rather than operating as a vehicle for income redistribution.

Higher and more diverse fees will compound the existing inequities as students enter the workforce. There is little direct relationship between earnings levels and the degree of debt or the length of study. Some students will have relatively large debts and low earnings (and hence will never be able to repay their loan), while others will be in the reverse situation. Those on low earnings may well face financial hardship while repaying their student loans. Equally, issues of hardship arise while students are studying. Bailey (1994a, 1994b) drew attention to many students having insufficient income, existing on scraps and sandwiches, while the student hardship committees have been faced with increased requests for assistance. Both of these phenomena would increase with higher fees.

\section{The problems of targeted assistance}

Option B was based on the view that under-representation by Maori and low-income people in tertiary education should be addressed quickly. Increased targeted assistance funded by those students who could comfortably afford to do so (as judged by their lifetime earnings) was proposed. The aim of Option B appeared to be more participation in tertiary education by those from low-income backgrounds; but such students under Option B would be required to pay higher fees. There are practical issues of how to target assistance. For instance, what criteria should be used for allocating the proposed expenditure of $\$ 200$ million that would be targeted? The suggested criteria in the Report included: low parental income, ethnicity, entry qualifications, and the duration of unemployment (p. 150).

Each of these criteria is beset with problems (St. John, 1994). For instance, would it be sensible to give the greatest state assistance to those least likely to succeed at formal tertiary education? Targeting on the basis of ethnicity is equally problematic. As the Report indicated, current tertiary participation rates among Maori have increased to almost the average New Zealand rate. However, low participation rates in the past mean that Maori have on average far lower skill levels than Pakeha. What is required is remedial post-experience training. But Option B was silent about retraining those suffering from inadequate education in the past.

Targeting on the basis of parental income also raises problems (e.g., relatively high EMTRs as the subsidy abates, administrative costs, stigma, etc.). Boston (1992b) provided a general assessment of targeting versus universal provision of services, much of which is pertinent to the tertiary education debate. He pointed out that targeting might not always produce the desired fiscal savings because of poor policy design or avoidance; that the efficiency gains from targeting might be illusory because of adverse incentive effects from high EMTRs; that targeting might reduce political support for a programme, so that the level of assistance provided to the poor was insufficient to meet their needs; that the administrative costs of targeting per dollar of assistance provided were high; and that the universal provision of a social service often had non-redistributive aims, such as social cohesion and racial tolerance.

Although advocates of Option B seemed to recognise these problems with targeting, they were nonetheless content to add a further $\$ 200$ million to the existing forms of targeted assistance. However, the Report made no suggestion as to how the proposed targeting criteria were to be implemented, except that further work should be done.

\section{Conclusions}

The funding of tertiary education remains one of the most controversial issues in the realm of education policy, not just in New Zealand but in many other OECD countries. Increased participation in the tertiary sector has resulted in greater fiscal expenditures at the same time as governments have come under pressure to reduce tax burdens. The response in many OECD countries has been an increase in fees combined 
with a shift from student allowances to loans. In most countries where fees have been introduced or increased, the primary aim has been to supplement the existing public expenditure on tertiary education in the interests of funding additional student places while maintaining the quality of the education provided. There has also been a continuing commitment to the notion of education as a citizenship right. Since 1991, the National Government has reduced funding per EFTS, with students paying a larger share of their course costs. Options A and B would increase the relative share of course costs borne by students still further. The net result would be not only higher average fees but also much greater fee differentiation. It is hard to reconcile such outcomes, and the justifications upon which they are based, with the Todd Report's claim that tertiary education is a right.

From a straight fiscal perspective, there is no need to make major changes in the method of funding higher education. The expected growth rate in student numbers is less than the forecast growth rate of the economy. Moreover, with the government budget now in surplus, resources are available to fund an expansion of tertiary education without raising tax rates. But the introduction of higher fees may eliminate the expected growth in student numbers, thereby leaving New Zealand without sufficient skilled personnel to operate as a successful competitive economy in the twenty-first century. Admittedly, wider earnings differentials may mitigate the impact of higher fees. But this will be offset by the higher EMTRs faced by graduates. Option B purported to have an objective of increasing participation by Maori and other disadvantaged groups: in practice, it is these very students who are most likely to be deterred by the fee levels proposed. Mature students, especially women, are also likely to be negatively affected by the proposal.

There are many issues which the Todd Report failed to address adequately. As noted earlier, no assessment of the fiscal costs of maintaining the existing fee structure was provided; nor was there a detailed analysis of the fiscal implications of Options A and B. Equally important, the Report contained no discussion regarding the quality of tertiary education, the ability of tertiary institutions to attract suitably qualified staff, or the research time available to staff: all of these are already under threat as tertiary institutions try to minimise fee increases. Further, given the supposed imperative of fiscal constraints, some discussion concerning the desirability of continuing the current policy of open entry into the university system might have been expected, together with an analysis of alternative policy options (e.g., a two-tier tertiary system with universities reverting to the status of elitist academic institutions and a more vocationally-oriented, and cheaper-per-EFTS, polytechnic sector).

There are further issues on which the Report failed to come to any firm conclusions, or even evaluate the relevant arguments. For example, Option A recommended gradual abolition of the Study Right/non-Study Right distinction which has resulted in fee differentiation in some tertiary institutions. Option B provided no discussion on the Study Right policy, though presumably the distinction would disappear with the move to 50 percent course fees. Equally, Option A recommended that the current funding of tuition costs through the EFTS system be maintained, while Option B argued that the EFTS system be phased out with government funding progressively redirected to students and trainees. This would have important implications for the management of tertiary institutions.

The debate on tertiary education is certain to continue. Quite apart from the issues discussed in the preceding analysis, the following matters are likely to raise controversy: the implications of capital charging for tertiary institutions; the appropriate governance structure of tertiary institutions; the degree of autonomy these institutions should have from direct governmental control; the implications of the entry of universities into the qualifications framework; the implications of the Public Finance Act 1989 for tertiary institutions (e.g., the funding of tuition costs on the basis of outputs); and the funding of research.

\section{Postscript}

Subsequent to the completion of this article the Government announced on 10 January, 1995 that it would implement Option A of the Report of the Todd Task Force. This means that students will be required to pay an average 25 percent of their course costs by 1999 .

\section{Note}

This figure is presumed to be the discounted average additional lifetime earnings of a male graduate compared to a school leaver with no qualifications. Note that the process of "discounting" involves establishing the present worth or value of a future sum of money. The "discount rate" will vary according to the time preferences and risk attitudes of the individuals concerned (or of investors generally). 


\section{References}

Bailey, G. "Student poverty growing problem", Evening Post, 9 August 1994a.

Bailey, G. "Poor students exist on scraps and sandwiches", Evening Post, 10 August 1994b.

Barr, N. "The White Paper on Student Loans", in Journal of Social Policy, 18:3,1987:409-417.

Bertram, G. "Middle Class Capture: A Brief Survey", in Royal Commission on Social Policy, The April Re port, III, Part 2, Wellington: Royal Commission on Social Policy, 1988.

Birch, B. Economic and Fiscal Outlook 1994, Wellington: GP Print, 30 June 1994.

Blaug, M. An Introduction to the Economics of Education, Harmonsworth: Penguin Books, 1970.

Blaug, M. "The Empirical Status of Human Capital Theory: A Slightly Jaundiced Survey", in Journal of Economic Literature, 14:3,1976:827-855.

Boston, J. The Future of New Zealand Universities, Wellington: Victoria University Press, 1988.

Boston, J. "The Funding of Tertiary Education: Rights and Wrongs", in J. Boston and P. Dalziel (eds) The Decent Society? Essays in Response to National's Economic and Social Policies, Auckland: Oxford University Press, 1992a.

Boston, J. "Targeting: Social Assistance for All or Just for the Poor?" in J. Boston and P. Dalziel (eds) The Decent Society? Essays in Response to National's Economic and Social Policies, Auckland: Oxford University Press, 1992b.

Boston, J. "Questions left unanswered in Task Force wake", Sunday StarTimes, 29 May 1994.

Boyd, S. and Wylie, C. Workload and Stress in New Zealand Universities, Wellington, New Zealand Council for Educational Research and The Association of University Staff of New Zealand, 1994.

Brooke, A-M. "Tough student loan terms: The Todd Report neglects questions of equity and practicality", The Dominion, 6 September 1994.

Brosnan, P. and Rea, D. "Rogernomics and the Labour Market", unpublished paper, Industrial Relations Centre, Victoria University of Wellington, 1991.
Catherall, C. "Many students owe more than $\$ 5000$, survey shows", The Dominion, 12 December, 1994.

Devlin, N., Hansen. P. and Knowles, S. "Universities: Who Benefits and who Should Pay?" Department of Economics, University of Otago, 1994.

Dutton, D. "A giant step backward”, The Dominion, 4 August 1994.

Glennerster, H. "The Economics of Education: Changing Fortunes", in N. Barr and D. Whynes (eds) Current Issues in the Economics of Welfare, London: MacMillan, 1993.

Jackson, E. "No one wants to pay up twice", The Dominion, 3 November, 1994.

McLeod, R. and Scobie, G. "Towards a More Equitable System of Funding Post-Compulsory Education and Training", unpublished paper, Wellington: Ministerial Consultative Group, 7 March 1994a.

McLeod, R. and Scobie, G. "Further Consideration of Our Earlier Proposals", unpublished paper, Wellington: Ministerial Consultative Group, 16 March 1994b.

Ministerial Consultative Group Report (The Todd Report), Funding Growth in Tertiary Education and Training, Wellington, 1994.

Ministry of Education, Education for the 21st Century: a Discussion Document, Wellington: Ministry of Education, 1993.

National Party, 1990. Education: Investing in Achievement, Wellington, 5 May, 1990.

New Zealand University Students' Association, Responses to the Todd Report, Wellington: September 1994.

New Zealand Vice-Chancellors' Committee, Newsletter, No.32, November, 1994.

OECD, Financing Higher Education: Current Patterns, Paris: OECD, 1990.

Pool, I. New Zealand Universities Until 2007: Demographic Structures and Changes, Wellington: New Zealand Vice-Chancellors Committee, 1987.

Poot, J. and Stephens, R. "Rates of Return on Human Capital", unpublished research, Economics Group, Victoria University of Wellington, 1994.

Richardson, R. Economic and Fiscal Outlook 1993, Wellington: GP Print, 1 July 1993.

Rosenberg, B. “The Todd Report: too radical and too many unanswered questions", Christchurch Press, 14 June 1994. 
Sapsford, D. and Tzannatos, Z. The Economics of Labour Markets, London: Macmillan, 1993.

Stephens, R. "Financing Education" in H. Manson (ed), New Zealand Annual Review of Education, 3, 1993a:9-36.

Stephens, R. “Radical Tax Reform in New Zealand”, in Fiscal Studies, 14:3, 1993b:45-63.

St John, S. "How higher student fees would hit the middle-income pocket", Christchurch Press, 22 July 1994.

St John, S. and Skilling, D. "The Tax Treatment of an Investment in Human Capital", unpublished paper, University of Auckland, August, 1994.

Tertiary Review Group, "Review of Study Right", Wellington: Ministry of Education, 1991.

Treasury, Economic Management, Wellington: Government Printer, 1984.

Treasury, Government Management: Volume II - Education Issues, Wellington: Government Printer, 1987.

Williams, G. "British Higher Education in the World League", in Oxford Review of Economic Policy, 8:2, Summer, 1992:146-158.

\section{The authors}

Bob Stephens is a Senior Lecturer in Public Policy at Victoria University of Wellington. His major areas of research are social policy, especially poverty, social security, education and income distribution, and the economic effects of tax reform.

Jonathan Boston is an Associate Professor in Public Policy at Victoria University of Wellington. His major areas of research are public sector management, ethics and public policy, higher education policy and political economy. 